\title{
The effects of introducing the Amazonian squirrel monkey on the behavior of the northeast marmoset
}

\author{
Fátima Luciana Miranda CAMAROTTI ${ }^{*}$, Valdir Luna da SILVA ${ }^{1}$, Maria Adélia Borstelmann de OLIVEIRA ${ }^{2}$ \\ 1 Universidade Federal de Pernambuco (UFPE). Departamento de Fisiologia e Farmacologia. Av. Professor Moraes Rêgo, 1235, Cidade Universitária, CEP 50730-000 Recife - PE, Brasil. \\ 2 Universidade Federal Rural de Pernambuco (UFRPE). Departamento de Morfologia e Fisiologia. Av. Manoel de Medeiros, s/n, Dois Irmãos, CEP 52171-900, Recife - PE, Brasil. \\ * Autor correspondente: lucianacamarotti@yahoo.com.br
}

\begin{abstract}
The squirrel monkey Saimiri sciureus, an endemic primate of the Amazonian Basin, has been introduced in many localities of the Atlantic Forest biome. Introduced exotic species gain a competitive advantage in their new environment because of a lack of natural predators, competitors or diseases. This advantage can result in a reduction in the resources for the endemic species. The aims of this work were to evaluate the level of adaptation, and monitor the forms of interaction and the impact caused by S. sciureus on the behavior of the native species Callithrix jacchus in the Saltinho Biological Reserve, Tamandaré, Pernambuco, Brazil. The behavior was assessed by use of scan sampling method, every $5 \mathrm{~min}$. A total of $382 \mathrm{~h}$ (191 h or 2,292 scans per group) of time sampling was performed. Sixteen interactions were recorded. The interaction index was low and represented $2.4 \%$ of the total observation time. Interactions were significantly higher during the dry season $(58.5 \%)$ relative to the rainy season (41.5\%). Callithrix jacchus was intolerant to the presence of S. sciureus and the last one was more tolerant during the interactions. In the presence of $S$. sciureus, $C$. jacchus eating, foraging, resting, socializing, and self-grooming behaviors were reduced while alertness was increased. Territorial behavior showed no significant difference. In the presence of $S$. sciureus, on average, the group of marmosets assembled at a higher layer of the forest stratum. The results might indicate a negative effect of $S$. sciureus on the native species, $C$. jacchus.
\end{abstract}

KEYWORDS: Exotic primate, Saimiri sciureus, Callithrix jacchus, interspecific interactions.

\section{Efeitos da introdução do macaco-de-cheiro amazônico sobre o comportamento do sagui-do-nordeste}

\section{RESUMO}

O mico-de-cheiro, Saimiri sciureus, uma espécie endêmica da Bacia Amazônica, tem sido introduzido com sucesso em muitas localidades do bioma Mata Atlântica. Espécies exóticas introduzidas adquirem uma vantagem competitiva em seu novo ambiente por causa da ausência de seus predadores naturais, resultando em uma redução dos recursos alimentares para as espécies endêmicas. Nossos objetivos foram avaliar o nível de adaptação e monitorar as formas de interaçáo e do impacto causado pelo $S$. sciureus sobre o comportamento da espécie nativa, Callithrix jacchus, na Reserva Biológica de Saltinho, Tamandaré, Pernambuco, Brasil. O comportamento foi estudado através do método de amotragem scan sampling a cada 5 minutos. Um esforço amostral de 382 h (191 h ou 2.292 scans por grupo) foi obtido. Dezesseis interaçôes foram registradas. O índice de interação foi baixo e representou 2,4\% to total de tempo de observaçáo. As interaçóes foram significantemente maiores na estaçáo seca $(58,5 \%)$ do que na estação chuvosa (41,5\%). Em termos de tipos de interação, $C$. jacchus foi intolerante à presença de $S$. sciureus, que por sua vez apresentou alto nível de tolerância. Na presença de $S$. sciureus, o C. jacchus reduziu a alimentação, forrageamento, descanso, comportamentos sociais e autocatação e aumentou o comportamento de alerta. O comportamento territorial não apresentou diferença significante. Na presença do S. sciureus, no geral, o grupo de saguis permaneceu em um estrato mais alto na floresta. Os resultados parecem indicar um possível efeito negativo do S. sciureus sobre a espécie nativa, C. jacchus.

PalaVRaS-Chave: Primata exótico, Saimiri sciureus, Callithrix jacchus, interações interespecíficas. 


\section{INTRODUCTION}

The introduction of exotic or allochthonous species corresponds to the accidental or intentional release of individuals into an area where they usually do not occur (Moura-Brito and Patrocínio 2006; Ruiz-Miranda et al. 2006). The introduced species may assume the role of competitors, reducing food resources and potentially introducing diseases to the new environment (Primack and Rodrigues 2001; MouraBrito and Patrocínio 2006). Such competition can occur in two forms (Begon et al. 2006): Firstly by exploration, when the species consumes the food of a particular territory and depleting the food stock of the other species. Secondly by interference, when the animal keeps individuals of another species away from resources through agonistic behaviors such as fighting and aggressive displays. When a species is potentially invasive, it has advantages that allow it to expand its territory, conquering new areas in the ecosystem and establishing itself as the dominant population (Valéry et al. 2008).

In 1987, approximately 25 Amazonian squirrel monkeys (Saimiri sciureus Linnaeus, 1758) were seized to combat illegal trafficking and were subsequently released in an area of the Atlantic Forest in the Saltinho Biological Reserve. At that time, the only reported native primate species in the reserve was the common marmoset, Callithrix jacchus (Linnaeus, 1758), which is a small, endemic species of northeast Brazil (Rylands et al. 2000). Squirrel monkeys live in social groups ranging in size from 25 to 75 individuals (Boinski 1999; Stone 2007) or more (Baldwin and Baldwin 1981) and tend to associate for long periods with other Amazonian primates such as Cebus, Callicebus, Saguinus, and Ateles (Terborgh 1983, MendesPontes 1997; Pinheiro et al. 2011). It is common for some sympatric primate species to maintain polyspecific associations for a considerable time each day. These associations offer benefits in foraging, feeding (Pook and Pook 1982; Fleagle et al. 1981; Podolsky 1990) locomotion and protection against predators (Peres 1993; Heymann 1995, 2011; Porter 2001. Although uncommon, squirrel monkeys may also be associated with or encounter other mammalian species such as coati Nasua nasua (Haugaasen and Peres 2008; Pinheiro et al. 2011), tayra Eira barbara (Haugaasen and Peres 2008), agoutis Dasyprocta prymnolopha and Dasyprocta leporina, and deer Mazama gouazoubira (Pinheiro et al. 2011). At first, nothing about the relation between $S$. sciureus and $C$. jacchus has been published and nothing about the nature of their behavior in this situation is known. Thus, we can expect any kind of relation between this two non-sympatric species. We hypothesized that the presence of $S$. sciureus modifies the behavior of the native primate, $C$. jacchus. Our goals were to evaluate their level of adaptation, and monitor the forms of interaction and the impact caused by the presence of $S$. sciureus on the behavior of the native species $C$. jacchus.

\section{MATERIALS AND METHODS}

\section{The study area and the Saimiri sciureus population}

The study was conducted in the Saltinho Biological Reserve (REBIO) $\left(08^{\circ} 43^{\prime} 09^{\prime \prime} \mathrm{S}\right.$ and $\left.35^{\circ} 10^{\prime} 11^{\prime \prime} \mathrm{W}\right)$, located between the municipalities of Rio Formoso and Tamandaré, in the South Coast of the State of Pernambuco, northeast of Brazil. The rainy season lasts from May to August (Lira et al. 2006). The REBIO is an area protected by the Brazilian Institute of Environment and Renewable Natural Resources-IBAMA, and has 548 ha of ombrophilous dense forest of secondary vegetation, with a hot-humid climate, annual average temperature are approximately 25 ${ }^{\circ} \mathrm{C}$ with annual rainfall ranging from 1,500 to $1,700 \mathrm{~mm}$. The REBIO is surrounded by sugar cane plantations. The local population maintains a rural economy characterized by agriculture and grazing. The population of $S$. sciureus introduced in the REBIO area has grown over the years. Through regular monitoring of their sleeping sites (bamboo groves of Bambusa sp.) the groups were seen to be composed of juvenile animals of various age classes, as well as adults at the reproductive stage. The appearance of new groups was also observed.

\section{Data collection}

One group of $S$. sciureus "M1" (nine animals) and two groups of C. jacchus, "A1" and "A2" (six and nine animals, respectively) were initially observed from September 2007 to January 2008. This period included selection of the study site, habituation and monitoring of the primates, and ascertain the existence of interactions between the two species (total $126 \mathrm{~h}$ of observation). None of the individuals was captured or tagged. Systematic collection of behavioral data was conducted between February and September 2008 with five to six days per month. The schedule covered the whole period of daily activity of the animals $(8-10 \mathrm{~h})$, resulting in $382 \mathrm{~h}$ of observation (2,292 scan sampling units) for both marmoset groups (191 h for each one). We used the ad libitum and the scan sampling behavioral sampling methods (Altmann 1974) with 1-min duration with 5-min intervals. An inter-species interaction was defined as any event involving a distance of less than $50 \mathrm{~m}$ between the two species (Eckardt and Zuberbühler 2004). All interactions began with the $S$. sciureus approaching to less than 50 meters of the marmosets. We classified the interactions into two distinct types, according to the observed behaviors: (1) Intolerance (Int) - if agonistic vocalizations, chases, fights, or other types of alertness or clashes occurred between species; and (2) Tolerance (Tol) - if no agonist behavior was observed during interactions. The behavioral categories displayed by $C$. jacchus in the 
absence and presence of $S$. sciureus were based on those described by Affonso et al. (2004) (Table 1). Five casual interactions between $S$. sciureus and non-monitored marmoset groups were recorded when the observer was moving to the observation post. In these instances, the same methodology applied to monitored groups, totalizing the observed behaviors during the scans. This data was included, except to compare the behavior between the two monitored groups of $C$. jacchus. The height of each individual was estimated using a hypsometer during each scan sample unit. Then, marmoset heights were averaged for each scan sample unit in the absence and presence of squirrel monkeys for analysis.

Table 1. Description of behavioral categories

\begin{tabular}{lcc}
\hline Behavior & Code & Description \\
\hline Foraging & FR & Searching for food \\
Eating & EA & Eating food \\
Resting & RE & Lying on a branch in a relaxed position \\
Alertness & AL & Being alert with a "scanning" look \\
\hline Territorial & TR & $\begin{array}{r}\text { Emitting frequent "long call" vocalizations, which } \\
\text { may be associated with persecutions, odor } \\
\text { markings, cries of alarm, and arched walking }\end{array}$ \\
Socializing & SO & $\begin{array}{r}\text { Behaving in an affiliative manner (picking another } \\
\text { group member, breastfeeding, transporting } \\
\text { infant(s), and playing) }\end{array}$ \\
\hline Self-grooming & GR & Grooming its own body \\
\hline
\end{tabular}

\section{Data analysis}

Statistical analysis was performed using Excel $^{\odot}$ and Statistica $6.0^{\circ}$. To calculate the interaction index $\left(\mathrm{I}_{\mathrm{i}}\right)$, the following formula was used: $I_{i}=\left(N_{S} / N_{T S}\right) \times 100$, in which $\mathrm{N}_{S}=$ number of scans in the presence of $S$. sciureus; and $\mathrm{N}_{\text {TS }}=$ total number of scans. Only the sum of interaction events of marmoset groups "A1" and "A2" was used for interaction index. We tested whether scan frequency with interactions differed between dry and rainy seasons using a Chi-square test. Behavioral data was compared using the WilcoxonMann Whithney test (Siegel 1975). We calculated the relative frequency of each behavior of common marmoset in the presence and absence of squirrel monkeys. Significance was set at $\mathrm{p} \leq 0.05$ bilaterally for all tests. The results test with statistical significance are shown on Table 2. Graphs were generated using Origin 8.0. This study was authorized by SISBIO/ICMBio under the protocol n. 13194-1.
Table 2. Results of statistical tests

\begin{tabular}{|c|c|}
\hline Comparison & Results \\
\hline $\begin{array}{l}\text { Interactions during } \\
\text { different season }\end{array}$ & $\begin{array}{c}\chi^{2}=6.072 ; p=0.001 ; 857 \text { total scans in dry } \\
\text { season and } 32 \text { scans with interaction; } 1,435 \\
\text { total scans in wet season and } 23 \text { scans with } \\
\text { interaction }\end{array}$ \\
\hline $\begin{array}{l}\text { Kinds of interaction } C \text {. } \\
\text { jacchus }\end{array}$ & $\begin{array}{c}\chi^{2}=5.086 ; p=0.02 ; 50 \text { total scans with } \\
\text { interaction, } 36 \text { intolerant }\end{array}$ \\
\hline $\begin{array}{l}\text { Kinds of interaction } S \text {. } \\
\text { sciureus }\end{array}$ & $\begin{array}{c}\chi^{2}=7.250 ; p=0.007 ; 50 \text { total scans with } \\
\text { interaction, } 37 \text { tolerant }\end{array}$ \\
\hline $\begin{array}{l}\text { Difference in forest } \\
\text { strata used by } C \text {. } \\
\text { jacchus between } \\
\text { presence and absence } \\
\text { of } S \text {. sciureus }\end{array}$ & $U=30.00 ; p<0.05 ; n 1=42 ; n 2=16$ \\
\hline $\begin{array}{l}\text { Behavior of } C \text {. jacchus. } \\
\text { Presence versus } \\
\text { absence of } S . \text { sciureus }\end{array}$ & $\begin{array}{l}\text { Resting: } U=15.89 ; p<0.05 ; n 1=42 ; n 2=11 \\
\text { Socializing: } U=16.97 ; p<0.05 ; n 1=42 ; n 2=11 \\
\text { Self-grooming: } U=21.50 ; p<0.05 ; n 1=42 ; \\
\quad n 2=11 \\
\text { Alertness: } U=9.548 ; p<0.05 ; n 1=42 ; n 2=11\end{array}$ \\
\hline $\begin{array}{l}\text { Behavior of } C \text {. jacchus } \\
\text { versus behavior of } \\
\text { S.sciureus }\end{array}$ & $\begin{array}{l}\text { Foraging: } U=6.53 ; p=0.05 ; n 1=11 ; n 2=11 \\
\text { Vigilance: } U=8.66 ; p<0.05 ; n 1=11 ; n 2=11\end{array}$ \\
\hline
\end{tabular}

\section{RESULTS}

A total of 16 interactions were recorded, 11 of which involved our two marmoset study groups and five opportunistic interactions with other marmoset groups. The interaction index was low, representing $2.4 \%$ of the total observation period and significantly higher in the dry $(58.5 \%)$ than in the rainy season (41.5\%), Table 2. Callithrix jacchus was intolerant to the presence of $S$. sciureus (Int $=72 \%$; Tol $=28$ ), whereas $S$. sciureus showed a high tolerance level (Int $=24.5 \%$; Tol $=75.5 \%$ ) Table 2.The duration of interaction events lasted from 2 to $45 \mathrm{~min}$ (Mean=13.0 $\mathrm{min} ; \mathrm{SD}=13.9 \mathrm{~min}$ ).

\section{Behavior and use of forest strata by Callithrix jacchus in the presence and absence of Saimiri sciureus}

The behavioral categories of foraging and eating were more commonly observed when $S$. sciureus individuals were absent. In the presence of the introduced species, these behaviors occurred prior to the interactions but were immediately interrupted. Resting, socializing, and self-grooming were all significantly higher in the absence of S. sciureus. Conversely, the behavioral category alertness was significantly higher in the presence of $S$. sciureus (Figure 1).

In terms of forest strata use, the group $\mathrm{A} 1$ of $C$. jacchus used a significantly higher height during the interactions with S. sciureus. Callithrix jacchus was normally located at a height between $8-18 \mathrm{~m}$ (Mean $=12.1 \mathrm{~m} ; \mathrm{SD}=2.76 \mathrm{~m})$ during interactions, and they were located at a height of $3-13 \mathrm{~m}$ (Mean $=6.6 \mathrm{~m} ; \mathrm{SD}=1.91 \mathrm{~m})$ in the absence of $S$. sciureus. The data showed no significant difference for group "A2" of C. jacchus. 
The height occupied by this group was $4-12 \mathrm{~m}$ (Mean $=6.3 \mathrm{~m}$; $\mathrm{SD}=2.94 \mathrm{~m})$ and $3-9 \mathrm{~m}($ Mean $=5.4 \mathrm{~m} ; \mathrm{SD}=1.56 \mathrm{~m})$ in the presence and absence of $S$. sciureus respectively. Together with the results obtained from group A1, this suggests a tendency to occupy higher forest strata in the presence of $S$. sciureus.

\section{Behavior of Callithix jacchus and Saimiri sciureus during interactions}

Callithrix jacchus spent less time foraging and more time in vigilance (alertness) than $S$. sciureus during interactions. Saimiri sciureus was far less vigilant than $C$. jacchus. Other behavioral categories such as eating, resting, social, and self-grooming and territorial did not show significant differences (Figure 2).

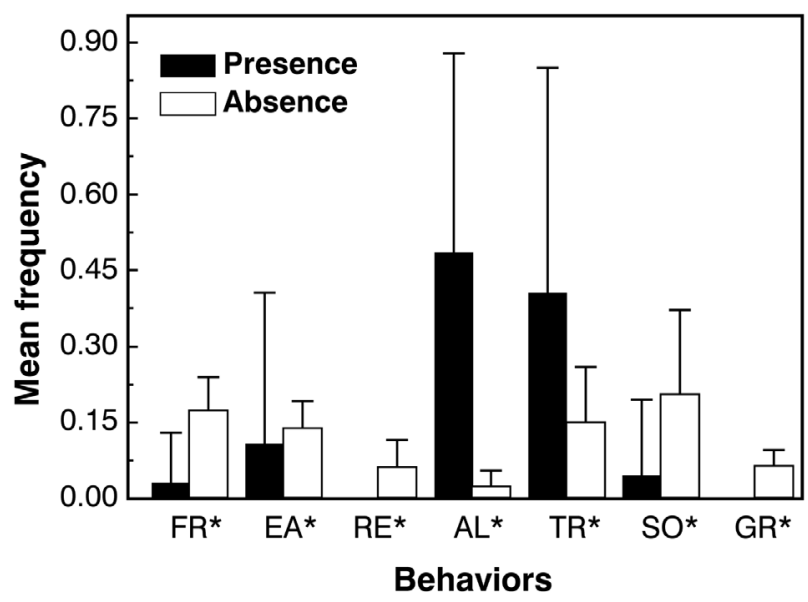

Figure 1. Mean frequency per scan of the behavioral categories shown by Callithrix jacchus in the presence and absence of Saimiri sciureus. $\mathrm{FR}=$ Foraging; $E A=$ Eating; $R E=$ Resting; $V G=$ Vigilance; $T R=$ Territorial; $S 0$ $=$ Socializing; $G R=$ Self-grooming. $\left({ }^{*} P \leq 0.05\right)$

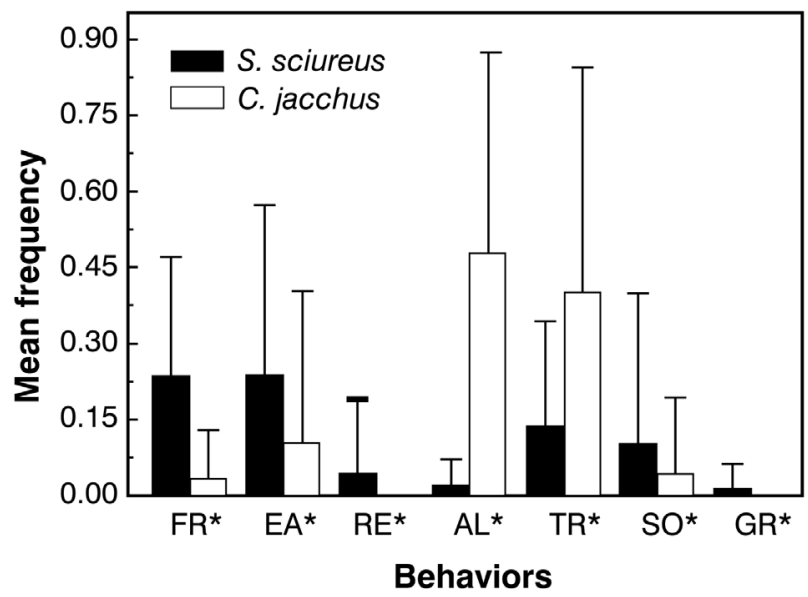

Figure 2. Mean frequency per scan of the behavioral categories during interactions between Saimiri sciureus and Callithrix jacchus.FR = Foraging; EA $=$ Eating; $\mathrm{RE}=$ Resting; $\mathrm{VG}=$ Vigilance; $\mathrm{TR}=$ Territorial; $\mathrm{SO}=$ Socializing; $\mathrm{GR}=$ Self-grooming. $\left({ }^{*} \mathrm{P} \leq 0.05\right)$

\section{DISCUSSION}

In this study, we observed a low frequency of interactions between $S$. sciureus and C. jacchus, with no clear evidence of cooperative behaviors between these species. In addition, the observed interactions did not indicate any kind of mutual advantage, which typifies polyspecific interactions common to species of the genus Saimiri in their natural habitat (Mendes-Pontes 1997; Heymann 2011; Pinheiro et al. 2011). When such mutual benefits occur, it is possible to observe the different primate species spending much of their daily activities within the same ecological niche (Terborgh 1983).

During the dry season, a period of food shortage, interactions between $S$. sciureus and $C$. jacchus occurred with significantly greater frequency than during the rainy season. In periods of food shortage, competition for food is increased which increased the probability of interactions between species. Saimiri sciureus can follow Cebus apella groups searching for food resources (Terborgh 1983), hence, "parasitizing" them, and making the association advantageous for only one species. We cannot rule out the possibility that $S$. sciureus "parasitizes" the marmoset, since the same food items were consumed by both, with the exception of the gums consumed exclusively by the marmosets (personal observation).

In the presence of $S$. sciureus, $C$. jacchus appear to change their behavioral repertoire, suggesting intolerance. Saimiri sciureus showed a significant degree of tolerance. The territorial behaviors that we observed between the groups of C. jacchus and $S$. sciureus have also been shown in a previous study by Ruiz-Miranda et al. (2006). In that case, C. jacchus was the introduced species and the native species was Leontopithecus rosalia. Although aggressive exhibitions were observed between C. jacchus and L. rosalia, an affiliative behavior of playing was also present. Affiliative behaviors were not observed between $C$. jacchus and S. sciureus in this study. Even for sympatric species such as $C$. kublii and $L$. chrysomelas, only aggressive behaviors were reported (Rylands 1989). Therefore, intolerance between primate species cannot be explained solely because one of them was an introduced species. Common marmosets chased the squirrel monkeys at least in pairs. Nevertheless, they appeared to avoid interactions with the squirrel monkeys by moving in opposite directions, hiding or going close to the ground.

During the interactions, the high rate of alertness by $C$. jacchus explained a reduction in their mobility. Nevertheless, there were aggressive displays and home range expulsion attempts against $S$. sciureus. Our results showed that only the group A1 of C. jacchus modified their height in response to the presence of S. sciureus. The home range of the group "A2" was overlapped with the $S$. sciureus sleeping site and this could have made this group more tolerant to their presence. However, the small amount of data does not permit confirmation. 
At the Saltinho Biological Reserve, S. sciureus individuals did not form a mixed group with $C$. jacchus. The two species may compete for food and space in the forest. Callithrix jacchus exhibited changes in their behavioral patterns in the presence and absence of $S$. sciureus, with a high rate of intolerance, indicating a possible negative effect of $S$. sciureus on the native species, $C$. jacchus. The low level of interaction could be a result of the sample effort that must be increased. Despite this, the current data shows that the behavior of $C$. jacchus changed in a significant way in the presence of S.sciureus. Specific data on food acquisition, reproduction and population survival are needed to provide a definitive conclusion.

The Saltinho Biological Reserve is reportedly native habitat of another primate, Sapajus flavius. This species is critically endangered and there are projects to reintroduce it into that area. Thus, we suggest that management measures be immediately implemented to control the expansion of the S. sciureus population.

\section{ACKNOWLEDGMENTS}

We acknowledge the Director of the Saltinho Biological Reserve, Luiz Façanha for providing logistical support and Cícero José da Silva (Saberé) for supporting the fieldwork. We are also grateful to Coordenaçáo de Aperfeiçoamento de Pessoal de Nível Superior-CAPES by granting the Master' scholarship.

\section{REFERENCES}

Altmann, J. 1974. Observational study of behavior: Sampling methods. Behavior, 49:227-267.

Baldwin, J.D.; Baldwin, J.I. 1981. The squirrel monkeys, genus Saimiri. In: Coimbra-Filho, A.B.; Mittermeier, R.A. (Eds.). Ecology and Behavior of Neotropical Primates. Academia Brasileira de Ciências, Rio de Janeiro, p. 277-330.

Begon, M.; Townsend, C.R.; Harper, J.L. 2006. Ecology: from individuals to ecosystems. 4a ed. Backwell Publishing, Oxford, 2006, 738p.

Boinski, S. 1999. The social organization of squirrel monkeys: implications for ecological models of social evolutions. Evolutionary Anthropology, 8:101-112.

Eckardt, W.; Zuberbühler, K. 2004. Cooperation and competition in two forest monkeys. Behavioral Ecology, 15:400-411.

Fleagle, J.G.; Mittermeier, R.A.; Skopec, A.L. 1981. Differential habitat use by Cebus apella and Saimiri sciureus in Central Surinam. Primates, 22:361-367.

Haugaasen, T.; Peres, C.A. 2008. Associations between primates and other mammals in a central Amazonian forest landscape. Primates, 49:219-222.

Heymann, E.W. 1995. Sleeping habits of tamarins, Saguinus mystax and Saguinus fuscicollis (Mammalia; Primates; Callitrichidae), in north-eastern Peru. Journal of Zoology, 237:211-226.
Heymann, E.W. 2011. Coordination in primate mixed-species groups. In: Boos, M.; Kolbe, P.M. Kapeller; Ellwart, T. (Eds.). Coordination in Human and Primate Groups, Berlin, Springer, p. 263-281.

Lira, V.M.; Oliveira, F.M.; Dantas, R.T.; Souza, W.M. 2006. Alterações da precipitação em municípios do Estado de Pernambuco. Engenharia Ambiental, 3:52-61.

Mendes-Pontes, A.R. 1997. Habitat partitioning among primates in Maracá Island, Roraima, Northern Brazilian Amazonian. International Journal of Primatology, 18:131-157.

Moura-Britto, M.; Patrocinio, D.N.M. 2006. A fauna de espécies exóticas no Paraná: contexto nacional e situação atual. In: Campos, J.B.; Tossulino, M. G. P.; Müller, C.R.C (Eds.). Unidade de Conservação: Açóes para Valorização da Biodiversidade, Instituto Ambiental do Paraná, Curitiba, p. 53-94.

Peres, C.A. 1993. Anti-predation benefits in a mixed-species group of Amazonian tamarins. Folia Primatologica, 61:61-76.

Pinheiro, T.; Ferrari, S.F.; Lopes, M.A. 2011. Polyspecific associations between squirrel monkeys (Saimiri sciureus) and other primates in Eastern Amazon. American Journal of Primatology, 73:1145-1151.

Pook, A.; Pook, G. 1982. Polyspecific association between Saguinus fuscicollis, Saguinus labiatus, Callimico goeldii and other primates in north-western Bolivia. Folia Primatologica, 38:196-216.

Podolsky, R.D. 1990. Effects of mixed-species association on resource use by Saimiri sciureus and Cebus apella. American Journal of Primatology, 21:147-158.

Porter, L.M. 2001. Benefits of polyspecific association for the Goeldi' smonkey (Callimico goeldii). American Journal of Primatology, 54:143-158.

Primack, R.B.; Rodrigues, E. 2001. Biologia da Conservaçâo, Editora Planta, Londrina, 2001, 327p.

Ruiz-Miranda, C.R.; Affonso, A.G.; Morais, M.M.; Verona, C.E.S.; Martins A.; Beck, B.B. 2006. Behavioral and ecological interactions between reintroduced golden tamarins (Leontopithecus rosalia Linnaeus, 1766) and introduced marmosets (Callithrix spp., Linnaeus, 1758) in Brazil Atlantic Coast Forest Fragments. Brazilian Archives Biology and Technology, 49: 99-109.

Rylands, A.B. 1989. Sympatric Brazilian Callitrichids: The black tufted-ear marmoset, Callithrix kuhli, and the golden-headed lion tamarin, Leontopithecus chrysomelas. Journal Human Evolution, 18:679-695.

Rylands, A.B.; Schneider, H.; Langguth, A.; Mittermeier, R.A., Groves, C.P.; Rodriguez-Luna E. 2000. An assessment of the diversity of new world primates. Neotropical Primates, 8:61-93.

Siegel, S. 1975. Estatística Não-Paramétrica: Para as Ciências do Comportamento. São Paulo: McGraw-Hill Ltda, São Paulo, 1975,350 p.

Stone, A.I. 2007. Age and seasonal effects on predator-sensitive foraging in squirrel monkeys (Saimiri sciureus): A field experiment. American Journal of Primatology, 69: 127-141.

Terborgh, J. 1983. Five new world primates: a study in comparative ecology. In: Krebs, J.R.; T. Clutton-Brock (Eds). Monographs in Behavior and Ecology, New Jersey: Princeton University Press, p.111-260. 


\section{ACTA}

Valéry, L.; Fritz, H.; Lefeuvre, J.C.; Simberlo, F.F.D. 2008. In search of a real definition of the biological invasion phenomenon itself. Biological Invasions, 10: 1345-1351.

Yoneda, M. 1984. Comparative studies on vertical separation, foraging behavior and traveling mode of saddle-back tamarins (Saguinus fuscicollis) and red-chested mustached tamarins (Saguinus labiatus) in northern Bolivia. Primates, 25:414-422.

Recebido em 23/01/2014

Aceito em 16/07/2014 